\title{
Relevance of the Knowles Theory in Distance Education
}

\author{
Derrick C. Darden \\ Tiffin University, Tiffin, USA \\ Email: dardendc@tiffin.edu, derrick.c.darden@gmail.com
}

Received 27 March 2014; revised 22 April 2014; accepted 10 May 2014

Copyright (c) 2014 by author and Scientific Research Publishing Inc. This work is licensed under the Creative Commons Attribution International License (CC BY). http://creativecommons.org/licenses/by/4.0/

\section{Abstract}

For adult learners, online courses are becoming the preferred way for students to pursue higher education. In the online academic world, the teacher and the student alike have duties that need to be fulfilled in order for the learning process to be successful. The teacher needs to function as process designers and managers. The learner must have the motivation and discipline to fulfill the course requirements and must be highly motivated. This article explores whether the Knowles andragogy theory is relevant to distance education or not and suggests the preferred relevant instructional style for today's adult distance learner. The andragogy model is based on four assumptions related to the concepts that adult distance learners must have the ability, need, the desire to control, and be responsible for their learning. The adult learners' self-prospective moves from dependency to independency or self-directedness. Furthermore, the teacher must have a more practical, relevant, and self-directive and self-motivated instructional style. The conclusion found that the andragogy theory is relative and is not a one-size-fits-all approach when it comes to adults following the assumptions outlined by andragogy model. Additionally, Knowles' theory promotes self-directing and independence in the adult learner, but not all adult learners embrace these ideals especially if the learner lacks self-confidence.

\section{Keywords}

Knowles Theory, Distance Education, Adult Learner, Self-Motivated, Self-Directedness, Instructional Style, Higher Education, Self-Confidence

\section{Introduction}

In the current era of learning, new teaching styles and methods are necessary to assist the adult learner in mastering new skills and accessing online information. As colleges adopt classroom and online technologies, teach- 
ers need to embrace the use of all types of classroom technology for future preparedness in the rapid rise of enrollment in distance learning programs (Kim \& Bonk, 2006). For the adult learner, online instruction (distance learning) has become the preferred way to continue their education sequentially to advance in their careers or train for new ones. Adults are enrolling in courses in record numbers. Many colleges are catering to them by providing distance learning, which allows flexibility and accessibility for the working adult. More than 12.2 million Americans take some form of online course in two or four year institution (Parsad \& Lewis, 2008; Kim \& Bonk, 2006).

Since adult learners are choosing to take college courses online; consequently, distance learning teaching styles must be re-tailored and teachers must establish a link to the adult learner. According to Grasha (1996), the linkage is a teacher-student transaction. The models must suit the learning style of the adult learner for there to be a connection between them. Adults and children learn differently and with different motivations. Among adult learning approaches, the model of andragogy comes to the forefront.

The first focus for this article is to look at the relevance of the andragogy model, and the second focus is to suggest the preferred relevant instructional style for today's adult distance learner.

\section{The Andragogy Model}

In the mid 1880s, Alexander Kapp coined the term “andragogy” as a description of Plato's educational theory. The name most associated with andragogy today is that of Malcolm Knowles who re-introduced the term in "The Modern Practice of Adult Education" when explaining his theory of adult learning. Knowles (1980) defines andragogy as the "art of science of helping adults learning" (p. 43).

Knowles' theory acknowledges that the adult learner is independent and self-directed. Adults have intrinsic motivation that relates to real life. Further, they are goal oriented; courses must be purposeful and practical (Bye, Pushkar, \& Conway, 2007) (as cited by Knowles, 1980). Andragogy focuses on adult learning and is identified solely with why the adult takes a course or undergoes training in the first place. Children, in contrast, do not have a wealth of knowledge and experience; hence the term pedagogy, therefore, they need structured training and teacher-directed learning - they depend on the teacher to direct their learning. Therefore, in andragogy the teacher must actively involve the adult learners in the process, and the topic must be from their perspective and of interest; they need to be aware of the importance of the content they're teaching. The teacher is a facilitator rather than the subject matter expert (Bye, Pushkar, \& Conway, 2007) (as cited by Knowles, 1980).

Knowles' andragogy model is based on four assumptions related to the concept that adult learners have the ability, need, and desire to control and be responsible for their learning: Their self-concepts move from dependency to independency or self-directedness. They accumulate a reservoir of experiences from which to draw new knowledge and skills. Their readiness to learn increases with the developmental tasks of social roles. Their time and curricular perspectives change from postponed to immediate application and from subject-centeredness to performance-centeredness.

\section{Distance Learning}

Increasingly, adults' preferred method of higher education is distance (online) learning because of the flexibility. Online teaching is a reality and enrollment in traditional classrooms is dwindling. An adult learner is busy and learning must be accessible and available on demand, however, without sacrificing a relationship with an instructor. Distance or online learning takes place when the teacher and learner are interacting in an instructional setting, usually not in the same location as an on-campus classroom.

Distance learning is here to stay and can be as effective as traditional learning (Hanson, Maushak, Schlosser, Anderson, Sorenson, \& Simonson, 1997). Trends indicate that learners will continue to move from the classroom to the computer (Ginder \& Sykes, 2013). Teachers must adapt teaching to the diversity of the classroom and online populations in order to connect with their students' learning goals and aspirations: adult learning requires positive correlations (Gee, 1990).

According to Forrest and Peterson (2006), adults take courses out of necessity, immediately seeking information. For example, they may need to improve their writing or communication skills for job growth, so they take an English or communication/speech class. In contrast, children are presumably learning in preparation for the future; therefore, applying lessons is not immediate. Andragogy incorporates real-life situations into adult education lesson plans. 


\section{Relevance to Today's Learning Environment}

When examining the relevance of distance learning and the model of andragogy, we find similar characteristics necessary for adult learners' successful learning experiences. To understand the value from distance learning, the learner must have the motivation and discipline to fulfill the course requirements: the learner must be highly motivated to achieve success in his or her coursework (Chen \& Lou, 2002).

Knowles (1980) notes that adult learners are autonomous and self-directing, self-motivating, and goal-oriented: they must see the course of study as useful and in their best interest.

Some researchers agree that andragogy when applied to distance education courses will help to promote selfdirection and independence in the adult learner (Fales \& Burges, 1984; Taylor \& Kaye, 1986).

In contrast, a few studies inconclusively determined that our idea of adult learners may not be appropriate. Burge (1988), in a study of Canadian students, concluded that not all adult learners prefer the andragogy methods: some adults are not self-directed because of lack of self-confidence. Another, study pointed to university students in the same region who agreed with the andragogical approach and manifested intrinsic motivation toward learning, but found no interest in self-directed learning (Robinson, 1992). These studies indicate that the assumptions outlined by the andragogy approach may differ from other methods; moreover, these studies make certain assumptions about adult characteristics that imply particular teaching and learning styles. Pratt (1988) argues that the determination of teaching styles should be situational, based on the connection between the teacher and learner. Furthermore, the Knowles assumptions such as self-directedness or autonomy may not be relevant or necessary.

If the andragogical approach is used in a distance-learning design, teachers must be sure that the Knowles assumptions are relevant and valid within the context of learning; else the intended benefit may become a detriment.

\section{The Teacher's Style Must Effectively Incorporate the Relevance of Skill}

Knowles, Holohn III, \& Swanson (2005) found that teachers must have full learner participation in a topic or project selection. Rather than being the classroom teacher, he suggests that teachers become facilitators of learning and need to involve all students in the learning experience. Adult learners need to connect with other learners to achieve fulfillment and to share information. Teachers need to help the learners realize the value of their experience and/or expertise.

Knowles et al. (2005) explain that the teacher must refrain from performing the function of content planner and transmitter, which requires presentation skills. Knowles continues: rather, teachers need to function as process designers and managers who require "relationship building needs assessment, involvement of student in planning, linking students to learning resource, and encouraging student initiative” (p. 254).

So, is the andragogy theory relevant to and effective in online distance adult learning in the twenty-first century? The answer is yes. Knowles' theory allows teachers to move from rudimentary methods of teaching to more practical, relevant, self-directed, and self-motivated strategies. Knowles' (1980) theory parallels adult learners' abilities, needs, and desires to control and be responsible for their learning.

Knowles' model of andragogy is well suited to the factors that affect adult learners in an online environment. Andragogy can help new teachers to design lesson plans and classwork by providing consistency, coherence, and direction to the adult learner-especially in the online classroom.

\section{Conclusion}

The classroom setting has moved beyond the teacher pontificating on textbook information in order to engage the non-motivated student. The online environment attracts the adult learner who recognizes that their career rides on furthering their education. Online courses allow them to take charge of their education, which means that the learner has already recognized that independence and self-discipline is required to have academic success. Within the distance learning context, Knowles' andragogy model optimizes the learning process to ensure that the adult learner acquires the information they will need in an ever-changing workforce. Because adult learners will have the advantage of an instructor who is their guide and facilitator, student-to-student relationships and access to shared information, they will fare better than brick-and-mortar students who may be younger and who are not yet able to take responsibility for their learning. Many adult distance learners are busy, mature peo- 
ple who have families. A significant majority has already entered the workforce and will regard their instructor not as a teacher, but as a field guide. "The future" for these adult learners may be nearer than those learners who only rely on the instructor to show them how to get there.

\section{References}

Burge, L. (1988). Beyond Andragogy: Some Explorations for Distance Learning Design. Journal of Distance Education, 3 , 5-23.

Bye, D., Pushkar, D., \& Conway, M. (2007). Motivation, Interest, and Positive Effect in Traditional and Nontraditional Undergraduate Students. Adult Education Quarterly, 57, 141-158. http://dx.doi.org/10.1177/0741713606294235

Chen, Y., \& Lou, H. (2002). Toward an Understanding of the Behavioral Intention to Use a Groupware Application. Journal of Organizational and End User Computing (JOEUC), 14, 1-16. http://dx.doi.org/10.4018/joeuc.2002100101

Fales, A. W., \& Burge, E. J. (1984). Self-Direction by Design: Self-Directed Learning in Distance Course Design. Canadian Journal of University Continuing Education, 10, 68-78.

Forrest, P. S. III, \& Peterson, T. O. (2006) Academy of Management Learning \& Education, 5, 113-122. http://dx.doi.org/10.5465/AMLE.2006.20388390

Gee, D. G. (1990). The Impact of Students' Preferred Learning Style Variables in a Distance Education Course: A Case Study. Portales: Eastern New Mexico University.

Ginder, S., \& Sykes, A. (2013). Web Tables: Characteristics of Exclusively Distance Education Institutions, by State: 201112, NCES 2013-172. National Center for Education Statistics. http://nces.ed.gov/pubs2013/2013172.pdf

Grasha, A. (1996). Teaching with Style. Pittsburg, PA: Alliance Publishers.

Hanson, D., Maushak, N. J., Schlosser, C. A., Anderson, M. L., Sorenson, C., \& Simonson, M. (1997). Distance Education: Review of the Literature (2nd ed.). Washington DC: Association for Educational Communications and Technology.

Kim, K., \& Bonk, C. J. (2006). The Future of Online Teaching and Learning in Higher Education: The Survey Says. Education Quarterly, 29, 22.

Knowles, M. (1980). The Modern Practice of Adult Education: From Andragogy to Pedagogy. Chicago: Associated.

Knowles, M. S., Holton, E. F., \& Swanson, R. A. (2005). The Adult Learner: The Definitive Classic in Adult Education and Human Resource Development. Boston: Taylor \& Francis Ltd.

Parsad, B., \& Lewis, L. (2008). Distance Education at Degree-Granting Postsecondary Institutions: $2006-07$ (NCES2009044). Washington DC: National Center for Education Statistics, Institute of Education Sciences, US Department of Education.

Pratt, D. (1988). Andragogy as a Relational Construct. Adult Education Quarterly, 38, 160-181. http://dx.doi.org/10.1177/0001848188038003004

Robinson, R. (1992). Andragogy Applied to the Open College Learner. Research in Distance Education, 10-13.

Taylor, E., \& Kaye, T. (1986). Andragogy by Design? Control and Self-Direction in the Design of an Open University Course. Programmed Learning and Educational Technology, 23, 62-69. 
Scientific Research Publishing (SCIRP) is one of the largest Open Access journal publishers. It is currently publishing more than 200 open access, online, peer-reviewed journals covering a wide range of academic disciplines. SCIRP serves the worldwide academic communities and contributes to the progress and application of science with its publication.

Other selected journals from SCIRP are listed as below. Submit your manuscript to us via either submit@scirp.org or Online Submission Portal.
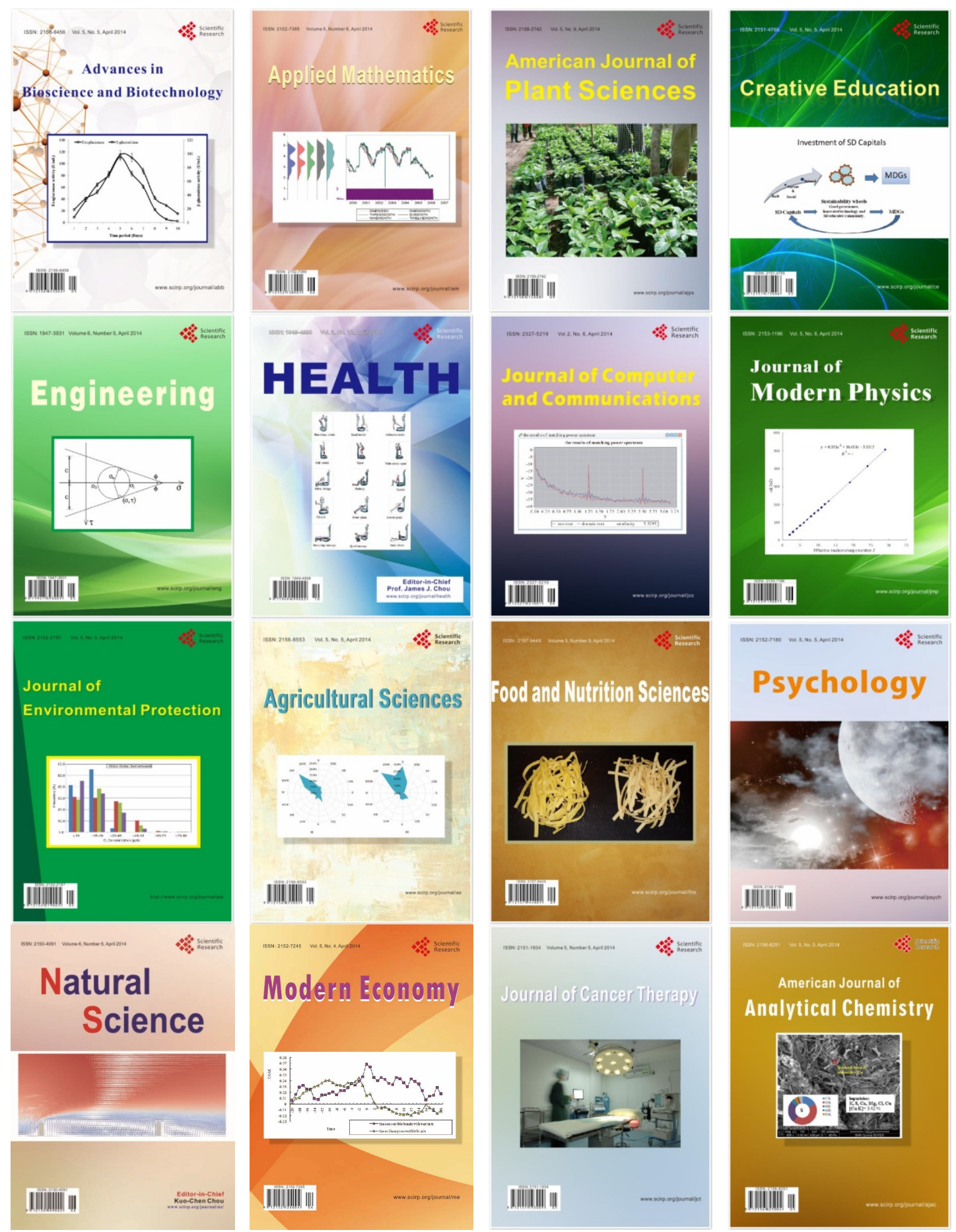